\title{
Bibliography of Finnish Population Studies 2010
}

\author{
SUVI JÄRVELIN, M.Sc. Information Specialist \\ The Population Research Instute, Väestöliitto, the Family Federation \\ of Finland, Helsinki, Finland
}

The bibliography covers the literature on population research published by Finnish authors in Finland and abroad during the year 2010. Also included are studies by foreign authors on Finnish population. Included are independent publications and articles in periodicals and compiled works as well as nationwide Finnish statistics. In general the bibliography excludes nonscientific articles in newspapers and weeklies as well as unpublished reports and academic theses. Also not included are studies presented in proceedings of conferences held in Finland if they are written abroad and treated subjects outside Finland. Neither are comparative studies where Finland not forms a substantial part included in the bibliography. Coverage is less complete in peripheral fields.

In principle the main divisions appearing in the Population Index have been used with added subdivisions better suiting Finnish circumstances. Studies covering several fields of demography, which should rightly be listed in two or more divisions, are included in only one division, i.e. in the division representing the primary field on which the report is centered.

Lists of literature on population research have been published in Yearbooks II-IV of the Family Federation of Finland, since 1960 in the Yearbook of Population Research in Finland and from 2006 onwards in the Finnish Yearbook of Population research.

\section{A. GENERAL POPULATION STUDIES AND THEORIES}

(No references)

\section{B. REGIONAL POPULATION STUDIES}

Terämä Emma. 2010. Regional demographic differences: the effect of laestadians. Finnish Yearbook of Population Research 45: 123-141.

Vilkama K. 2010. Kaupungin laidalla: kantaväestön ja maahanmuuttajataustaisten alueellinen eriytyminen Helsingissä. Terra 122 (4): 183-200.

\section{SPATIAL DISTRIBUTIONS}

Heikkilä E. and Pikkarainen M. 2010. Differential population development in the regions of Finland. Population, Space and Place 16 (4): 323-34.

Lehtonen Olli and Tykkyläinen Markku. 2010. Kuinka väestö sijoittuu siirryttäessä tietoyhteiskuntaan? Esimerkkinä Itä-Suomi. Yhteiskuntapolitiikka 75 (5): 498-516. 


\section{TRENDS IN POPULATION GROWTH AND SIZE}

Bandell J. 2010. Demografisk utveckling i Stockholm = Tukholman väestönkehitys. Kvartti: Helsingin Kaupungin Tietokeskuksen Neljännesvuosijulkaisu (3): 7-14.

Helsingin väestöennuste 2011-2050. 2010. Tilastoja 2010: 31. Helsinki: Helsingin kaupungin tietokeskus. 88 pp.

Helsingin väestö vuodenvaihteessa 2009/2010 ja väestönmuutokset vuonna $2009=$ Helsingfors befolkning vid årsskiftet 2009/2010 och befolkningsförändringar år 2009. 2010. Helsinki: Helsingin kaupungin tietokeskus. Tilastoja 2010 (1). 146 pp.

Myrskylä Mikko. 2010. Elämme toistakymmentä vuotta elinajanodotetta pidempään. Tieto \& trendit (1): 16-22.

The state of Helsinki region 2009: European comparisons. 2010. Helsinki: City of Helsinki Urban Facts, Statistics and Information Service. 55 pp. ISBN 978-952-223490-2 (pdf).

\section{E. MORTALITY}

Ahlm K., Hassler S., Sjölander P. and Eriksson A. 2010. Unnatural deaths in reindeerherding Sami families in Sweden, 1961-2001. International Journal of Circumpolar Health 69 (2): 129-37.

Giltay Erik J., Zitman Frans G., Menotti Alessandro, Nissinen Aulikki, Jacobs Jr. David R., Adachi Hisashi, Kafatos Antony and Kromhout Daan. 2010. Respiratory function and other biological risk factors for completed suicide: 40 years of followup of European cohorts of the Seven Countries Study. Journal of Affective Disorders 120 (1-3): 249-253.

Herttua, Kimmo. The effects of the 2004 reduction in the price of alcohol on alcoholrelated harm in Finland: a natural experiment based on register data. Finnish Yearbook of Population Research 45 (suppl.). 100 pp. + app. Doctoral dissertation.

Kahila Hanna, Gissler Mika, Sarkola Taisto, Autti-Rämö Ilona and Halmesmäki Erja. Maternal welfare, morbidity and mortality $6-15$ years after a pregnancy complicated by alcohol and substance abuse: a register-based case-control follow-up study of 524 women. 2010. Drug and alcohol dependence 111 (3): 215-221.

Korpi Helena. 2010. Lapsikuolleisuuden väheneminen ilmentää yhteiskunnan muutosta ja kehitystasoa. Hyvinvointikatsaus (2): 38-41.

Lehmijoki Ulla and Palokangas Tapio. 2010. Demographic and economic consequences of the post-war mortality decline in developing countries. Discussion papers 642. Helsinki: University of Helsinki, Department of Economics. 27 pp. ISBN 978-952-10-5354-2. 
Liettu A., Mikkola L., Säävälä H., Räsänen P., Joukamaa M. and Hakko, H. 2010. Mortalityrates of males who commit parricide or other violent offense against a parent. Journal of the American Academy of Psychiatry and the Law Online 38 (2): 212-220.

Mäki Netta. 2010. Not in all walks of life? Social differences in suicide mortality. Research Reports, Department of Sociology 262. Helsinki: University of Helsinki. 193 pp. ISBN 978-952-10-6088-5 (pdf). Doctoral dissertation.

Mäki Netta and Martikainen Pekka. 2010. A register-based study on excess suicide mortality among unemployed men and women during different levels of unemployment in Finland. Journal of epidemiology and community health (October 21).

Myrskylä Mikko. 2010. The Relative Effects of Shocks in Early- and Later-Life Conditions on Mortality. Population and Development Review 36 (4): 803-829.

Sipilä Petteri and Martikainen Pekka. 2010. Language-group mortality differentials in Finland: the effects of local language composition. Health \& Place 16 (3): 446-451.

Tarkiainen Lasse, Martikainen Pekka, Laaksonen Mikko and Leyland Alastair H. 2010. Comparing the effects of neighbourhood characteristics on all-cause mortality using two hierarchical areal units in the capital region of Helsinki. Health \& Place 16 (2): 409-412.

Vanhatalo Jarno, Mäkelä Pia and Vehtari Aki. 2010. Alkoholikuolleisuuden alueelliset erot Suomessa 2000-luvun alussa. Yhteiskuntapolitiikka 75 (3): 265-273.

\section{F. FERTILITY}

Alvergne A., Jokela M. and Lummaa V. 2010. Personality and reproductive success in a high-fertility human population. Proceedings of the National Academy of Sciences of the United States of America 107 (26): 11745-11750.

Basten Stuart. 2010. Television and Fertility. Finnish Yearbook of Population Research 45: 67-82.

Cunningham Solveig A., Elo Irma T., Herbst Kobus and Hosegood Victoria. 2010. Prenatal development in rural South Africa: relationship between birth weight and access to fathers and grandparents. Population Studies 64 (3): 229-246.

Falah-Hassani K., Kosunen E., Shiri R. and Rimpelä A. 2010. The use of the vaginal ring and transdermal patch among adolescent girls in Finland. European Journal of Contraception and Reproductive Health Care 15 (1): 31-34.

Gissler Mika. 2010. Registration of Births and Induced Abortions in the Nordic Countries. Finnish Yearbook of Population Research 45: 171-178. 
Larivaara Meri M. 2010. Pregnancy prevention, reproductive health risk and morality: a perspective from public-sector women's clinics in St. Petersburg, Russia. Critical Public Health 20 (3): 357-371.

Madkour Aubrey S., Farhat Tilda, Halpern Carolyn T., Godeau Emmanuelle and Gabhainn Saoirse N. 2010. Early Adolescent Sexual Initiation and Physical/Psychological Symptoms: A Comparative Analysis of Five Nations. Journal of Youth and Adolescence 39 (10): 1211-1225.

Miettinen Anneli. 2010. Voluntary or Involuntary Childlessness? Socio-Demographic Factors and Childlessness Intentions among Childless Finnish Men and Women. Finnish Yearbook of Population Research 45: 5-24.

Orpo Olli-Pekka. 2010. Turvatonta seksiä. Kehitys (3): 48-53.

Sirkiä Jouni. 2010. Improving Sexual Health Awarness and Services of Young People in the District of Vyborg 2006-2009. Final evaluation 2010. Helsinki: Väestöliitto. 38 pp. ISBN978-952-226-067-3.

Säävälä Minna. 2010. Finnish Official Development Aid for sexual and reproductive health and rights in sub-Saharan Africa. Finnish Yearbook of Population Research 45: 143-170.

Vapaus valita. Seksuaali-ja lisääntymisterveys sekä -oikeudet Suomen kehityspolitiikassa. 2010. Helsinki: Ulkoasiainministeriö, kehitysviestintä. 29 pp.

Virkkunen Joni, Uimonen Pirjo and Davydova Olga. 2010. Ethnosexual processes: realities, stereotypes and narratives. Helsinki: Aleksanteri-instituutti, Kikimora Publications. 210 pp. ISBN 978-952-10-6567-5.

Vuori Pekka. 2010. Syntyneisyys äidinkielen mukaan Helsingin seudulla 2000-luvulla = Nativiteten i olika språkgrupper i Helsingforsregionen på 2000-talet. Kvartti : Helsingin kaupungin tietokeskuksen neljännesvuosijulkaisu (1): 20-26.

Väisänen Heini and Jokela Markus. 2010. Fertility after Induced Abortion: a Register-Based Study in Finland in 2000-2008. Finnish Yearbook of Population Research 45: 25-44.

\section{G. NUPTIALITY AND FAMILY}

Hämäläinen Ulla and Kangas Olli (eds.). 2010. Perhepiirissä. Helsinki: KELA, Kelan tutkimusosasto. 320 pp. ISBN 978-951-669-831-4.

Hakovirta Mia. 2010. Lapsiköyhyys ja lapsen elatus vanhempien eron jälkeen. Yhteiskuntapolitiikka 75 (3): 293-302.

Hämäläinen Hans and Tanskanen Antti. 2010. Perhesukupolvet ja taloudellinen auttaminen: suurten ikäluokkien lapsilleen ja vanhemmilleen antama tuki. Janus 18 (4): 374-386. 
Kontula Osmo. 2010. Lastenhankinta -koettelemus isien seksuaalisille toiveille. In: Jämsä Juha and Kalliomaa Susa (eds.), Isyyden kielletyt tunteet. pp. 76-86. Helsinki: Väestöliitto. ISBN 978-952-226-054-3.

Lainiala Lassi. 2010. Perhepolitiikan uudet tuulet: perheen paluu. Helsinki: Väestöliitto, Väestöntutkimuslaitos. Katsauksia E 39. 63 pp. ISBN 978-952-226-057-4.

Lyngstad Torkild and Jalovaara Marika. 2010. A review of the antecedents of union dissolution. Demographic Research 23 (article 10): 257-292.

Nikander Timo. 2010. Avioliiton suosio on hitaasti kasvanut. Hyvinvointikatsaus (2): 20-23.

Pääkkönen Hannu. 2010. Perheiden aika ja ajankäyttö. Tutkimuksia kokonaistyöajasta, vapaaehtoistyöstä, lapsista ja kiireestä. Helsinki: Tilastokeskus. 256 pp. ISBN 978-952-244-248-2 (pdf).

Tanskanen Antti, Danielsbacka Mirkka and Jokela Markus. 2010. Kenen lapsiin isovanhemmat investoivat? Isyyden epävarmuus ja hypoteesi varmimman sukulaisen suosimisesta. Yhteiskuntapolitiikka 75 (2): 121-130.

Temkina Anna. 2010. Childbearing and Work-Family Balance among Contemporary Russian Women. Finnish Yearbook of Population Research 45: 83-101.

\section{H1 INTERNATIONAL MIGRATION}

Andersson Roger, Dhalmann Hanna, Holmqvist Emma, Kauppinen Timo M., Magnusson Turner, Lena Skifter, Andersen Hans, Söholt Susanne, Vaattovaara Mari, Vilkama Katja, Wessel Terje and Yousfi Saara. 2010. Immigration, housing and segregation in the Nordic welfare states. Helsinki: University of Helsinki, Department of Geosciences and Geography. 285 pp. ISBN 978-952-10-6770-9 (pdf).

Dhalmann Hanna. 2010. Yhteisöllisyyttä ilman alueellista keskittymistä: venäläisten maahanmuuttajien toiveet naapuruston etnisestä koostumuksesta. Terra 122 (3): 125-135.

Haikkola Lotta. 2010. Etnisyys, suomalaisuus ja ulkomaalaisuus toisen sukupolven luokitteluissa. In: Tuomas Martikainen and Lotta Haikkola (eds.), Maahanmuutto ja sukupolvet, pp. 219-238. Helsinki: Suomalaisen kirjallisuuden seura.

Harinen Päivi and Ronkainen Jussi. "Uusi tuuli puhaltaa, painaa pilviin juuret": monikulttuuriset nuoret ja kulttuurisen erilaisuuden puolustus. In: Tuomas Martikainen and Lotta Haikkola (eds.), 2010, Maahanmuutto ja sukupolvet, pp. 273-290. Helsinki: Suomalaisen kirjallisuuden seura.

Hyvönen Heli. 2010. Rajan yli -naiset muuttajina Suomen ja uudelleen itsenäistyneen Viron välillä. Naistutkimus 23 (1): 52-56. 
Janhonen-Abruquah Hille. 2010. Gone with the wind? Immigrant women and transnational everyday life in Finland. Home Economics and Craft Studies Research Reports 24. Helsinki: University of Helsinki, Faculty of Behavioural Sciences, Department of Teacher Education. 192 pp. 978-952-10-6135-6. Doctoral dissertation.

Juntunen Elina, Laiho Marjukka and Pessi Anne B. 2010. Uskonnolliset yhteisöt ja maahanmuuttajien hyvinvointi. Teologinen aikakauskirja 115 (1): 3-22.

Kilpi Elina. 2010. Toinen sukupolvi peruskoulun päättyessä ja toisen asteen koulutuksessa. 2010. In: Tuomas Martikainen and Lotta Haikkola (eds.), Maahanmuutto ja sukupolvet, pp. 110-132. Helsinki: Suomalaisen kirjallisuuden seura.

Kulla Gunilla E., Ekman Sirkka-Liisa, Heikkilä, A. K. and Sarvimäki and Anneli M. 2010. Differences in self-rated health among older immigrants: a comparison between older Finland-Swedes and Finns in Sweden. Scandinavian Journal of Public Health 38 (1): $25-31$.

Kääriäinen Juha, Ellonen Noora, Peutere Laura and Sariola Heikki. 2010. Lapset ja nuoret väkivallan uhreina: maahanmuuttajien ja kantasuomalaisten vertailua. Yhteiskuntapolitiikka-75 (2): 159-174.

Linnanmäki-Koskela Suvi and Niska Ari. 2010. Maahanmuuttajien integroituminen Suomen omistusasunto- ja työmarkkinoille $=$ Invandrarnas integration på den finländska ägarbostads- och arbetsmarknaden. Kvartti: Helsingin kaupungin tietokeskuksen neljännesvuosijulkaisu (2): 51-63.

Mannila Simo, Messing Vera, van den Broek Hans-Peter and Vidra Zsuzsanna. 2010. Immigrants and Ethnic Minorities. European Country Cases and Debates. Report 41. Helsinki: Terveyden ja hyvinvoinnin laitos. 105 pp. ISBN978-952-245-393-8.

Martikainen Tuomas and Haikkola Lotta (eds.). 2010. Maahanmuutto ja sukupolvet. Helsinki: Suomalaisen kirjallisuuden seura. 299 pp. ISBN 978-952-222-212-1.

Myrskylä Pekka. 2010. Maahanmuutossa suuria vuosivaihteluita. Tieto \& trendit (4-5): 30-36.

Peltola Marja. 2010. Ulossuljettu keskiluokka? Maahanmuuttajataustaiset nuoret, perhe ja yhteiskunnallinen asema. In: Tuomas Martikainen and Lotta Haikkola (eds.), Maahanmuutto ja sukupolvet, pp. 66-83. Helsinki: Suomalaisen kirjallisuuden seura.

Pöyhönen Sari, Tarnanen Mirja, Vehviläinen Eeva-Maija, Virtanen Aija and Pihlaja Lenita. 2010. Osallisena Suomessa: kehittämissuunnitelma maahanmuuttajien kotoutumisen edistämiseksi. Jyväskylä: Jyväskylän yliopisto, soveltavan kielentutkimuksen keskus. 179 pp. ISBN 978-951-39-4101-7. 
Rauhut Daniel. 2010. Integration of Immigrants in Sweden 1945-1975. 2010. Finnish Yearbook of Population Research 45: 103-122.

Raunio Mika, Hammar-Suutari Sari and Säävälä Minna. 2010. Kohti tulevaisuuden kaupunkiyhteisöä? Monikulttuurisuus ja maahanmuuttajat Helsingin, Joensuun ja Tampereen kaupunkien startegiossa. Alue ja ympäristö 39: 40-54.

Sallinen-Gimpl Pirkko. 2010. The encounter of the orthodox and lutheran original population with the evacuees in North Karelia. Ethnologia Fennica 37: 86-101.

Säävälä Minna. 2010. Forced Migrants, Active Mothers or Desired Wives: Migratory Motivation and Self-Representation in Kosovo Albanian and Russian Women's Biographies. Journal of Ethnic and Migration Studies 36 (7): 1139-1155.

Söderling Ismo. 2010. On sitä liikuttu ennenkin -siirtolaisuuden lyhyt historia. In: Clarke Kris, Folkersma Liisa, Hirvonen Ulla, Lepola Outi, Sund Ralf ja Söderling Ismo, Meno-paluu Eurooppaan. Maahanmuutto ja siirtolaisuus eilen, tänään - ja huomenna, pp. 6-12. Helsinki: Eurooppalainen Suomi. ISBN 978-952-5891-03-4 (pdf).

Söderling Ismo. 2010. Suomalainen muuttoliike osana eurooppalaista ja globaalia väestökysymystä. In: Heikkinen Timo ja Mynttinen Eeva (eds.), Kollaasikaupunki, pp. 9-26. Helsinki: Aalto University, School of Science and Technology.

Teräs Marianne, Lasonen Johanna and Sannino Annalisa. Maahanmuuttajien lasten siirtymät koulutukseen ja työelämään. In: Tuomas Martikainen and Lotta Haikkola (eds.), Maahanmuutto ja sukupolvet, pp. 85-109. Helsinki: Suomalaisen kirjallisuuden seura.

Valkonen, Sanna. 2010. Politics of the Sami Culture. Politiikka 52 (2): 140-144.

\section{H2 INTERNAL MIGRATION}

Kytö Hannu and Väliniemi Jenni. 2010. Asuminen ja työpaikat ohjaavat pääkaupunkiseudun muuttovirtoja. Hyvinvointikatsaus (3): 12-15.

Mullonen Juho. 2010. Uutta ja tosiasiapohjaista tietoutta inkerinsuomalaisten kohtalokkaista vuosista. Carelia 12: 107-110.

Nivalainen Satu. 2010. Essays on family migration and geographical mobility in Finland. PTT julkaisuja 21. Helsinki: Pellervon taloustutkimus. 192 pp. ISBN 978952-224-049-1 (pdf). Doctoral disseration.

Saari Matti. 2010. Miljoona muuttoa vuodessa. Hyvinvointikatsaus (3): 8-11.

Tuorila Helena. 2010. Mieluisan asunnon vuoksi ajetaan pitkiäkin matkoja omalla autolla. Hyvinvointikatsaus (3): 16-19. 
Vilkko Anni, Suikkanen Asko and Järvinen-Tassopoulos Johanna (eds.). 2010. Kotia paikantamassa. Rovaniemi: Lapin yliopistokustannus. 337 pp. 978-952-484-353-9.

\section{HISTORICAL DEMOGRAPHY AND DEMOGRAPHIC HISTORY}

Badanov Vadim. 2010. Karjalan väestö 1400-1600 -luvulla. Carelia (8): 134-136.

Hasu Päivi. 2010. Villi avioliitto ja morsian karkuteillä: saksalainen lähetystyö ja muuttuvat avioitumisen muodot Kilimanjarolla 1893-1940. In: Seija Jalagin, Olli Löytty \& Markku Salakka (eds.), Kaikille kansoille: lähetystyö kulttuurien vuoropuhelun, pp. 154-179. Helsinki: Suomalaisen kirjallisuuden seura.

Häggman Kai and Anttila Anu-Hanna. 2010. Suomalaisen arjen suuri tarina. Helsinki: WSOY. 364 pp. ISBN 978-951-0-36732-2.

Kavén Pertti. 2010. Humanitaarisuuden varjossa. Poliittiset tekijät lastensiirroissa Ruotsiin sotiemme aikana ja niiden jälkeen. Helsinki: Helsingin yliopisto, Humanistinen tiedekunta, Filosofian, historian, kulttuurin ja taiteiden tutkimuksen laitos. 332 pp. ISBN978-952-92-8318-7. Doctoral dissertation.

Saloheimo, Veijo. 2010. Entisen esivallan alle uusille elosijoille: ortodoksikarjalaisten ja inkeroisten poismuutto 1500- ja 1600-luvuilla. Joensuu: Pohjois-Karjalan historiallinen yhdistys. 218 pp. 978-952-99525-3-3.

Sundell Tarja and Onkamo Päivi. 2010. Argeopop: keramiikasta geenivirtoihin? Muinaistutkija (1): 3-8.

\section{J. CHARASTERISTICS}

Fågel Stina, Rotkirch Anna and Söderling Ismo. 2010. Farkkumummoja ja pehmovaareja. Uusia ikkunoita isovanhemmuuteen. Helsinki:Väestöliitto, VL-markkinointi. 176 pp. ISBN978-952-226-049-9.

Laaksonen Mikko and Silventoinen Karri. 2010. Sosiaaliepidemologia. Väestön terveyserot ja terveyteen vaikuttavat tekijät. Helsinki: Gaudeamus. 301 pp. ISBN978952-495-171-5.

Eriksson Ilse. 2010. Sukupolvivastuu ja huolenpito omista vanhemmista. Gerontologia 24 (4): 302-312.

Erola Jani. 2010. Kohorttien väliset liikkuvuuserot: haaste suomalaisen yhteiskunnan avoimuudelle. Yhteiskuntapolitiikka 75 (3): 318-323.

Finnäs Fjalar. 2010. Befolkningsutvecklingen i Svenskfinland. In: Susan Sundback och Fredrica Nyqvist (eds.), Det finlandssvenska sociala kapitalet: fakta och fiction, pp. 29-43. Helsingfors: Svenska Litteratursällskapet. ISBN-10: 9515831946. 
Haataja Anita. 2010. Taustatietoa vuonna 2006 äitiys- ja vanhempainrahaa saaneiden äitien demografisista ja toimeentuloon liittyvistä tekijöistä Kela-Stakes-tutkimusaineistossa. Nettityöpapereita 9. Helsinki: Kela, Kelan tutkimusosasto. 45 pp.

Hoppania Hanna-Kaisa. 2010. Lapsiköyhyys ja perheiden koettu hyvinvointi pääkaupunkiseudulla $=$ Fattigdom i barnfamiljer och upplevt välstånd i familjer i Huvudstadsregionen. Kvartti: Helsingin kaupungin tietokeskuksen neljännesvuosijulkaisu (2): $17-30$.

Johnson Wendy, Deary Ian J., Silventoinen Karri, Tynelius Per and Rasmussen Finn. 2010. Family Background Buys an Education in Minnesota but Not in Sweden. Psychological Science 21 (9): 1266-1273.

Kulla G., Ekman S. and Sarvimäki A. 2010. Experiential health from an ageing and migration perspective: the case of older Finland-Swedes. Journal of Immigrant and Minority Health 12 (1): 93-9.

Markkanen Sanna. 2010. Toisen sukupolven koulumenestyksen ymmärtäminen ja tutkiminen Suomessa. In: Tuomas Martikainen and Lotta Haikkola (eds.), Maahanmuutto ja sukupolvet, pp. 133-148. Helsinki: Suomalaisen kirjallisuuden seura.

Moisio Pasi and Kauppinen Timo M. 2010. Toimeentulotuen asiakkuus periytyy vanhemmilta lapsille. Hyvinvointikatsaus (1): 21-24.

Mortensen Laust H., Lauridsen Jorgen T., Diderichsen Finn, Kaplan George A., Gissler Mika and Andersen Anne-Marie N. 2010. Income-related and educational inequality in small-for-gestational age and preterm birth in Denmark and Finland 1987-2003. Scandinavian Journal of Public Health 38 (1): 40-45.

Paavola Heini and Talib Mirha-Tytti. 2010. Kulttuurinen moninaisuus päiväkodissa ja koulussa. Jyväskylä: PS-Kustannus. 241 pp. ISBN978-952-451-481-1.

Pietilä Ilkka and Ojala Hanna. 2010. Miesten vanheneminen 2000-luvun Suomessa: näkökulmia muuttuviin arkielämän käytäntöihin ja yhteiskuntapolitiikkaan. Futura 29 (3).

\section{K. DEMOGRAPHIC AND ECONOMIC INTERRELATIONS AND NATURAL RESOURCES}

Aittomäki Akseli, Martikainen Pekka, Laaksonen Mikko, Lahelma Eero and Rahkonen Ossi. 2010. The associations of household wealth and income with self-rated health -A study on economic advantage in middle-aged Finnish men and women. Social science \& medicine 71 (5): 1018-1026.

Asa Riikka and Muurinen Heidi. 2010. Maahanmuutto työvoiman tarpeen täyttäjänä? Helsinki: European Migration Network. 97 pp. ISBN 978-952-5920-00-0. 
Hublin Christer, Partinen Markku, Koskenvuo Karoliina, Silventoinen Karri, Koskenvuo Markku and Kaprio Jaakko. 2010. Shift-work and cardiovascular disease: a populationbased 22-year follow-up study. European Journal of Epidemiology 25 (5): 315-323.

Huttunen Hannu-Pekka and Äärilä Suvi (eds.). 2010. Avoin Suomi -kuka vastaa? Työperusteisesta maahanmuutosta. Helsinki: Elinkeino-, liikenne- ja ympäristökeskus. 306 pp. ISBN978-952-257-182-3.

Kautto Mikko. 2010. Työurat ja eläketurvan riittävyys. Yhteiskuntapolitiikka 75 (3): 311-317.

Laakso S. and Loikkanen H. A. 2010. Aluetaloudet muutoksessa -maailmanlaajuisesti = regionekonomierna förändras -globalt. Kvartti: Helsingin Kaupungin Tietokeskuksen Neljännesvuosijulkaisu (1): 7-19.

Laaksonen M., Mastekaasa A., Martikainen P., Rahkonen O., Piha K. and Lahelma E. 2010. Gender differences in sickness absence: the contribution of occupation and workplace. Scandinavian Journal of Work, Environment and Health 36 (5): 394-403.

Lahelma E., Lallukka T., Laaksonen M., Martikainen P., Rahkonen O., Chandola T., Head J., Marmot M., Kagamimori S., Tatsuse T. and Sekine M. 2010. Social class differences in health behaviours among employees from Britain, Finland and Japan. The influence of psychosocial factors. Health \& Place 16 (1): 61-70.

Lehmijoki Ulla. 2010. Väestöllinen transitio muuttaa maailman. In: Marja-Liisa Halko, Anne Mikkola and Olli-Pekka Ruuskanen (eds.), Naiset, miehet ja talous, pp. 197-212. Helsinki: Gaudeamus. ISBN 978-952-495-115-9.

Lehto Anna-Maija and Sutela Hanna. 2010. Ikääntyvien työpanos on vahvassa kasvussa. Tieto \& trendit (2): 18-23.

Leifsen Esben and Tymczuk Alexander. 2010. Care and connectivity in labour migration. Suomen antropologi 35 (4): 49-52.

Muutoksen sukupolvi: kriiseistä ja konflikteista uuteen alkuun: tiivistelmä YK:n väestörahaston vuosiraportista [State of the world population 2010]. Helsinki: Väestöliitto, UNFPA. 54 pp. ISBN 978-952-226-059-8.

Mäkinen T., Kestilä L., Borodulin K., Martelin T., Rahkonen O., Leino-Arjas P. and Prättälä R. 2010. Occupational class differences in leisure-time physical inactivity: contribution of past and current physical workload and other working conditions. Scandinavian Journal of Work, Environment and Health 36 (1): 62-70.

Palomäki Liisa-Maria ja Tuominen Eila. 2010. Työssä käyvät eläkeläiset: erot muihin 
työssä käyviin ja eläkkeellä oleviin. Eläketurvakeskuksen keskustelualoitteita 2010 (4). Helsinki: Eläketurvakeskus. 38 pp.

Rajaniemi Jouko. 2010. Ravintola-ala ulkomaalaistuu - etenkin pääkaupunkiseudulla. Tieto \& trendit (7): 32-34

Ruotsalainen Kaija. 2010. Ulkomaalaisten yrittäjyys yleisempää kuin muun väestön. Tieto \& trendit (7): 30-32.

Sarvimäki Matti. 2010. Maahanmuuton taloustiede lyhyt johdatus. Kansantaloudellinen aikakauskirja 106 (3): 253-270.

Sinokki M., Ahola K., Hinkka K., Sallinen M., Härmä M., Puukka P., Klaukka T., Lönnqvist J. and Virtanen M. 2010. The association of social support at work and in private life with sleeping problems in the Finnish health 2000 study. Journal of occupational and environmental medicine 52 (1): 54-61.

Sjöblom-Immala Heli. 2010. Kymmenen vuotta Suomeen tulosta: maahanmuuttajat työmarkkinoilla. Alue ja ympäristö 39: 61-68.

Työllisyyskertomus vuodelta 2009. 2010. Helsinki: Työ- ja elinkeinoministeriö. 192 pp. ISBN 978-952-227-364-2.

Volanen Salla-Maarit, Suominen Sakari, Lahelma Eero, Koskenvuo Karoliina, Koskenvuo Markku and Silventoinen Karri. 2010. Sense of coherence and intentions to retire early among Finnish women and men. BMC Public Health 10 (22).

Wrede Sirpa and Nordberg Camilla (eds.). 2010. Vieraita työssä: työelämän etnistyvä eriarvoisuus. Helsinki: Palmenia, Helsinki University Press. 285 pp. ISBN 978-951-570-776-5.

\section{DEMOGRAPHIC AND NONECONOMIC INTERRELATIONS}

Bloomfield Kim, Wicki Matthias, Gustafsson Nina-Katri, Mäkelä Pia and Room Robin. 2010. Changes in Alcohol-Related Problems After Alcohol Policy Changes in Denmark, Finland and Sweden. Journal of Studies on Alcohol and Drugs 71 (1): 32-40.

Einiö Elina K. 2010. Determinants of institutional care at older ages in Finland. Finnish Yearbook of Population Research 45 (suppl). 96 pp. + app. Doctoral dissertation.

Haarni Ilkka, Hautamäki Lotta and Aro Mari. 2010. Life experience and alcohol: 60-75-year-olds' relationship to alcohol in theme interviews. Nordisk alkohol- \& narkotikatidskrift 27 (3): 241-258.

Hankonen Nelli, Absetz Pilvikki, Ghisletta Paolo, Renner Britta and Uutela Antti. 2010. Gender differences in social cognitive determinants of exercise adoption. Psychology \& Health 25 (1): 55-69. 
Helakorpi Satu, Mäkela Pia and Uutela Antti. 2010. Alcohol Consumption before and after a Significant Reduction of Alcohol Prices in 2004 in Finland: Were the Effects Different across Population Subgroups? .Alcohol and Alcoholism 45 (3): 286-292.

Konttinen Hanna, Männistö Satu, Sarlio-Lähteenkorva Sirpa, Silventoinen Karri and Haukkala Ari. 2010. Emotional eating, depressive symptoms and self-reported food consumption. A population-based study. Appetite 54 (3): 473-479.

Koskenvuo K., Hublin C., Partinen M., Paunio T. and Koskenvuo M. 2010. Childhood adversities and quality of sleep in adulthood: a population-based study of 26,000 Finns. Sleep Medicine 11 (1): 17-22.

Laitalainen Elina, Helakorpi Satu and Uutela Antti. 2010. Eläkeikäisen väestön terveyskäyttäytyminen ja terveys keväällä 2009 ja niiden muutokset 1993-2009. Raportti 2010 (30). Helsinki: Terveyden ja hyvinvoinnin laitos. 173 pp. ISBN 978-952-245-326-6 (pdf).

Lehtovirta M., Pietiläinen K. H., Levälahti E., Heikkilä K., Groop L., Silventoinen Karri, Koskenvuo M. and Kaprio J. 2010. Evidence that BMI and type 2 diabetes share only a minor fraction of genetic variance: a follow-up study of 23,585 monozygotic and dizygotic twins from the Finnish Twin Cohort Study. Diabetologia 53 (7): 1314-1321.

Pärna Kersti and Ringmets Inge. 2010. Comparison of socioeconomic differences in self-perceived health in Estonia and Finland. Scandinavian Journal of Public Health 38 (2): 129-134.

Silventoinen K., Rokholm B., Kaprio J. and Sørensen T. I. A. 2010. Genetic and environmental influences on childhood obesity: systematic review of twin and adoption studies. International Journal of Obesity 34: 29-40.

Silventoinen K., Sundström J., Tynelius P., Eriksson J. and Rasmussen F. 2010. Ethnic differences in blood pressure in young men living in similar environment: a study of international adoptees in Sweden. Journal of Hypertension 28 (7): 1393-1399.

Singh-Manouxa Archana, Gourmelena Julie, Ferrieb Jane, Silventoinen Karri, Guéguena Alice, Stringhinia Silvia, Hermann Nabi and Kivimäki Mika. 2010. Trends in the association between height and socioeconomic indicators in France, 1970-2003. Economics \& Human Biology 8 (3): 396-404.

Wennerstad K. M., Silventoinen K.., Tynelius P., Bergman L., Kaprio J. and Rasmussen F. Associations between IQ and cigarette smoking among Swedish male twins. Social Science \& Medicine 70 (4): 575-581

Wennerstad Karin M., Silventoinen Karri, Tynelius Per, Bergman Lars and Rasmussen Finn. 2010. Association between intelligence and type-specific stroke: a population- 
based cohort study of early fatal and non-fatal stroke in one million Swedish men. Journal of Epidemiology and Community Health 64: 908-912.

\section{POLICIES}

Helin Heikki. Kuntien optimaalinen väestöpohja vaihtelee toiminnoittain. 2010. Tieto \& trendit (1): 30-32.

Ikääntyvä Etelä-Savo: palvelu- ja osaamistarpeiden suuntaviivoja. 2010. Mikkeli: Etelä-Savon elinkeino-, liikenne- ja ympäristökeskus. 15 pp. ISBN 978-952-257066-6 (pdf).

Iikkanen Päivi. 2010. Keski-Suomen maahanmuuttopoliittinen ohjelma. Keski-Suomen elinkeino-, liikenne- ja ympäristökeskuksen julkaisuja 2010 (2). Jyväskylä: KeskiSuomen elinkeino-, liikenne- ja ympäristökeskus. 53 pp. ISBN 978-952-257-041-3.

Keränen Heikki and Rontti Sami. 2010. Pohjois-Pohjanmaan maahanmuuttostrategia 2015. Pohjois-Pohjanmaan ELY-keskuksen julkaisusarja 2010 (2). Oulu: Pohjois-Pohjanmaan elinkeino-, liikenne- ja ympäristökeskus. 88 pp. ISBN 978-952-257-024-6.

Seksuaalikasvatuksen standardit Euroopassa. Suuntaviivat poliittisille päättäjille, opetusja terveydenhoitoalan viranomaisille ja asiantuntijoille. 2010. Köln; Helsinki: BZgA Federal Centre for Health Education, suomennos Terveyden ja hyvinvoinnin laitos. 61 pp.

Ristenrauna Magga. 2010. Saamelaisten sosiaali- ja terveyspalvelujen kehittämisen haasteet Suomessa. Yhteiskuntapolitiikka 75 (6): 670-678.

Ritamo Maija, Pelkonen Marjaana and Nikula Minna. 2010. Seksuaali-ja lisääntymisterveyden edistäminen: väliarviointi sosiaali-ja terveysministeriön toimintaohjelmasta vuosille 2007-2011. Avauksia 2010 (6). Helsinki: Terveyden ja hyvinvoinnin laitos. $19 \mathrm{pp}$.

Salmi Minna and Lammi-Taskula Johanna. 2010 6+6+6-malli vanhempainvapaan uudistamiseksi. Päätöksen tueksi 2010 (1). Helsinki: Terveyden ja hyvinvoinnin laitos. 8 pp.

Sannisto T., Saaristo V., Ståhl T., Mattila K. and Kosunen E. 2010. Quality of the contraceptive service structure: a pilot study in Finnish health centre organisations. European Journal of Contraception and Reproductive Health Care 15 (4): 243-54.

Shemeikka Riikka. 2010. Finnish Official Development Aid for Sexual and Reproductive Health and Rights in Sub-Saharan Africa. Finnish Yearbook of Population Research 45: 143-170.

Vaarama Marja, Moisio Pasi and Karvonen Sakari (eds.). 2010. Suomalaisten hyvinvointi 2010. Helsinki: Terveyden ja hyvinvoinnin laitos. 288 pp. ISBN 978-952-245-365-5. 


\section{N. METHODS OF RESEARCH AND ANALYSIS INCLUDING MODELS} (No references)

\section{O. THE PRODUCTION OF POPULATION STUDIES (No references)}

\section{P. PROFESSIONAL MEETINGS AND CONFERENCES}

17th Nordic Demographic Symposium, June 17-19 th Lund 2010. Program: http:// www.demografi.se/jamnews/documents/NDS2010_Program.pdf. 10 pp.

Nuorten hyvin- ja pahoinvointi, konsensuskokous 2010. Helsinki: Duodecim, Suomen Akatemia. 131 pp. ISBN978-952-67123-3-8.

\section{Q. BIBLIOGRAPHIES, DIRECTORIES AND OTHER INFORMATION SERVICES}

Helamaa Tiina. 2010. Bibliography of Finnish Population Studies 2007-2009. Finnish Yearbook of Population Research 45: 179-208.

Jussila R. 2010. Seksisanat: Suuri suomalainen seksisanakirja. Espoo: Prometheus. 856 pp. ISBN 978-952-5718-12-6.

\section{R. NEW PERIODICALS}

(No references)

\section{S. OFFICIAL STATISTICAL PUBLICATIONS}

Official Statistics of Finland, Tilastokeskus, Helsinki

\section{Causes of death}

Kuolemansyyt $2008=$ Dödsorsaker $=$ Causes of death .2010 . Helsinki: Tilastokeskus. 148 pp. ISBN 978-952-244-235-2.

Kuolemansyyt $2009=$ Dödsaker $=$ Causes of Death .2010. Helsinki:

Tilastokeskus. $10 \mathrm{pp}$.

\section{Censuses}

Rakentaminen ja asuminen: vuosikirja $2010=$ Construction and Housing: yearbook 2010. 2010. Helsinki: Tilastokeskus. 209 pp. ISBN978-952-244-277-2.

Economic activity

Työvoimatutkimus- Aikasarjatiedot 2000-2009. 2010. Helsinki: Tilastokeskus. 91 pp. 


\section{Families}

Perheet 2009 $=$ Familjer $=$ Families. 2010. Helsinki: Tilastokeskus. 43 pp.

\section{Migration}

Ulkomaalaiset ja siirtolaisuus $2007=$ Foreigners and international migration $=$ Utlänningar och migration. 2010. Helsinki: Tilastokeskus. 82 pp. ISBN 978-952244-030-3.

\section{Population projections}

Väestöennuste kunnittain 2009-2040 = Befolkningsprognos kommunvis = Population projection by municipality. 2010. Helsinki: Tilastokeskus. 124 pp. ISBN978-952-244-267-3.

\section{Population structure}

Väestörakenne ja väestönmuutokset kunnittain $2008=$ Befolkningens sammansättning och befolkningsförändringar kommunvis = Population structure and vital statistics by municipality. 2010. Helsinki: Tilastokeskus. 195 pp. ISBN978-952-244-109-6.

Väestörakenne ja väestönmuutokset kunnittain $2009=$ Befolkningens sammansättning och befolkningsförändringar kommunvis = Population structure and vital statistics by municipality. 2010. Helsinki: Tilastokeskus. 188 pp. ISBN978-952-244-266-6.

\section{Vital statistics}

Väestönmuutokset $2008=$ Befolkningsförändringar $=$ Vital Statistics. 2010. Helsinki: Tilastokeskus. 166 p. ISBN978-952-244-207-9.

Väestönmuutokset 2009 = Befolkningsförändringar $=$ Vital Statistics. 2010. Helsinki: Tilastokeskus. 164 pp. ISBN978-952-244-278-9.

\section{Population statistics and projections by other institutions}

Miettinen Anneli. 2010. Population Data on Finland 1900-2009. Finnish Yearbook of Population Research 45: 209-218.

Päihdetilastollinen vuosikirja 2010. Alkoholi ja huumeet = Statistisk årsbok om alkohol och narkotika. Statistical Yearbook of Alcohol and Drug Statistics 2010. 2010. Helsinki: Terveyden ja hyvinvoinnin laitos. 151 pp. ISBN 978-952-245-404-1 (pdf).

Sosiaali-ja terveydenhuollon tilastollinen vuosikirja $2010=$ Statistisk årsbok om socialvård och hälso- och sjukvård = Statistical yearbook on social welfare and health care . 2010. Helsinki: Terveyden ja hyvinvoinnin laitos. 274 pp. ISBN978-952-245-402-7.

Synnyttäjät ja synnytystoimenpiteet sairaaloittain 2008-2009 = Föderskor och förlossningsingrepp per sjukhus. 2010. Helsinki: Terveyden ja hyvinvoinnin laitos. 16 pp. + app. 